\title{
What do I miss in today's electrochemistry?
}

\author{
Fritz Scholz ${ }^{1}$
}

Received: 16 March 2020 / Revised: 16 March 2020 / Accepted: 16 March 2020 / Published online: 25 March 2020

(C) The Author(s) 2020

The world community of electrochemists produces large numbers of publications. Judged from the numbers of journal publications, now electrochemistry comes probably on place two following biochemistry. The technological advancements of electrochemistry have a global impact on all societies. Searching for new ideas reveals many tiny ideas (also necessary), but only very few great ideas. This is something natural, and not surprising. Great ideas nucleate and grow in single brains, and very rarely. They need feeding from a prolific environment, although exceptions are known. I do not dare to foretell the future of electrochemistry, because the appearance of breakthrough ideas cannot be forecasted. The only thing we can do is to analyse the present state and to say what is needed. When we know what is needed, we may decide to go this way. However, all scientists work in a socio-political and economic environment, which has its own rules, and, unfortunately for the development of science, it rewards (e.g. with funds) research goals, which are often set by politicians disregarding innate needs of science and inspired by the desire to please their voters. The career of scientists benefits most from funding and from publishing in high-impact journals. The unprecedented pressure to publish is not only the gravedigger of journals but also an immoral seducer. I wished that the hunting for projects (funds) would be substituted by the hunting for ideas. Ideas need to come first, then the projects. However, now, many people first think about possible project applications and how to bring the demanded number of research groups from the demanded number of participating countries together, before thinking about an idea. Since we cannot change easily these circumstances of scientific research, we have to give the younger generation an example how to resist as good as possible and how to concentrate on those tasks which we identify from purely scientific points of

Fritz Scholz

fscholz@uni-greifswald.de

1 Institut für Biochemie, Universität Greifswald, Felix-Hausdorff-Str. 4, 17489 Greifswald, Germany view, of course including the demands of the society! There is also another consequence of the pressure to publish and need to get funding for the research: some of the most creative electrochemists, who made themselves a name with fundamental studies of great importance, have later turned to applied electrochemistry and to those projects for which they could get much easier funds, than for basic research. Although they were also very successful in the new fields of study, I count it as regrettable that they left the fundamental studies.

What are the tasks which I have identified? The first task is general: we should publish only findings which are as safe as possible. If we will do so, the volume of published literature will reduce by probably two-thirds. We need to go away from publishing "more of the same". Especially in electroanalysis and corrosion, but also in battery materials, I see a flood of uninspired papers with minute variations and without any practical use. The fact that even such uninspired papers can tell others, what is not worse to be studied, poses the question, how should such information be published? Now, we have only the answer, to put it in low-valued journals. I see that the number of carefully performed studies to establish solid and important thermodynamic data is very much decreasing. We are now still profiting from the studies performed in the $50 \mathrm{~s}$ and 60s of the twentieth century (I am thinking of the many contributions from the Sillén group in Sweden), and even from the decades before. This is clearly the result of funding policy. You may argue that such studies may be also uninspired, as they would use very classical approaches. Yes and no. Some would use the classical approaches, but they would produce very necessary data. New ideas also came up and proved to be useful [1]. What do I miss specifically in the small fields of electrochemistry which I try to oversee? In bioelectrochemistry, we know many redox systems which transfer electrons across membranes, but we know not much about the effects of membrane composition on the thermodynamics and kinetics of charge transfer [2] and not much about real 
medium effects of cells and cell organelles on dissolved or membrane-bound redox systems. In insertion electrochemistry, which is so important for batteries, we do not know much about the single Gibbs contributions of ion and electron transfer [3]. If we will know these contributions and understand them on the basis of theoretical calculations and structure consideration, we will be able to develop batteries in a more serious and less empirical way. In the area of electroanalysis, we really need fresh ideas and should give up developing and publishing methods which cannot compete with other techniques, unless they are smart ideas which may find other applications.

Also in future, electrochemistry will be blessed by most genius ideas to understand much deeper its fundaments and by developments which widen its applications. All we can do for this is (a) care for the educational system, (b) care for an inspiring and fair research atmosphere in our groups, (c) show students how rewarding it is to understand the unknown and to get new insight by elegant experiments, and (d) secure the necessary funding by addressing decision makers and politicians. Referring to education, we should not forget to imbed the present state of knowledge in a presentation of the historical pathways. Only this can assure a holistic understanding of science. It may also save us from following ideas which, already in the past, have proven to be wrong or useless. With the following words, the great scientist and historian George Sarton (Gent, Belgium, Aug. 31, 1884 - Cambridge, USA, March 22, 1956) emphasised the importance of including science history in science teaching [4]: "Nothing is better fitted to awaken a pupil's critical sense and to test his vocation than to retrace for him in detail the complete history of a discovery, to show him the trammels of all kinds that constantly arise in the inventor's path, to show him also how one surmounts them or evades them, and lastly how one draws closer and closer to the goal without ever reaching it. Besides, this historical initiation would cure the young students of the unfortunate habit of thinking that science began with them."

Acknowledgements Open Access funding provided by Projekt DEAL.

Open Access This article is licensed under a Creative Commons Attribution 4.0 International License, which permits use, sharing, adaptation, distribution and reproduction in any medium or format, as long as you give appropriate credit to the original author(s) and the source, provide a link to the Creative Commons licence, and indicate if changes were made. The images or other third party material in this article are included in the article's Creative Commons licence, unless indicated otherwise in a credit line to the material. If material is not included in the article's Creative Commons licence and your intended use is not permitted by statutory regulation or exceeds the permitted use, you will need to obtain permission directly from the copyright holder. To view a copy of this licence, visit http://creativecommons.org/licenses/by/4.0/.

\section{References}

1. Scholz F, Gulaboski R (2005) Determination of Gibbs energies of ion transfer across water/organic liquid interfaces with three-phase electrodes. ChemPhysChem 6(1):16-28

2. Heise N, Scholz F (2017) Assessing the effect of the lipid environment on the redox potentials of the coenzymes Q10 and Q4 using lipid monolayers made of DOPC, DMPC, TMCL, TOCL, and natural cardiolipin (nCL) on mercury. Electrochem Commun 81:141144

3. Scholz F, Doménech-Carbó A (2019) The thermodynamics of insertion electrochemical electrodes-a team play of electrons and ions across two separate interfaces. Angew Chem Int Ed 19:3279-3284

4. Sarton G (1960) The life of science. Essays in the history of civilisation. Indiana University Press, Bloomington, p 50

Publisher's note Springer Nature remains neutral with regard to jurisdictional claims in published maps and institutional affiliations. 